\title{
Increased renal sodium absorption by inhibition of prostaglandin synthesis during fasting in healthy man. A possible role of the epithelial sodium channels
}

Thomas G Lauridsen ${ }^{1,2^{*}}$, Henrik Vase ${ }^{1,2}$, Jørn Starklint ${ }^{1,2}$, Carolina C Graffe ${ }^{1,2}$, Jesper N Bech ${ }^{1,2}$, Søren Nielsen ${ }^{3}$, Erling B Pedersen ${ }^{1,2}$

\begin{abstract}
Background: Treatment with prostaglandin inhibitors can reduce renal function and impair renal water and sodium excretion. We tested the hypotheses that a reduction in prostaglandin synthesis by ibuprofen treatment during fasting decreased renal water and sodium excretion by increased absorption of water and sodium via the aquaporin2 water channels and the epithelial sodium channels.

Methods: The effect of ibuprofen, $600 \mathrm{mg}$ thrice daily, was measured during fasting in a randomized, placebocontrolled, double-blinded crossover study of 17 healthy humans. The subjects received a standardized diet on day 1 , fasted at day 2, and received an IV infusion of $3 \% \mathrm{NaCl}$ on day 3. The effect variables were urinary excretions of aquaporin2 (u-AQP2), the beta-fraction of the epithelial sodium channel (u-ENaCbeta), cyclic-AMP (u-cAMP), prostaglandin E2 (u-PGE2). Free water clearance $(\mathrm{CH} 2 \mathrm{O})$, fractional excretion of sodium (FENa), and plasma concentrations of vasopressin, angiotensin II, aldosterone, atrial-, and brain natriuretic peptide.

Results: Ibuprofen decreased u-AQP2, u-PGE2, and FENa at all parts of the study. During the same time, ibuprofen significantly increased $u$-ENaCbeta. Ibuprofen did not change the response in p-AVP, u-c-AMP, urinary output, and free water clearance during any of these periods. Atrial-and brain natriuretic peptide were higher.

Conclusion: During inhibition of prostaglandin synthesis, urinary sodium excretion decreased in parallel with an increase in sodium absorption and increase in u-ENaCbeta. U-AQP2 decreased indicating that water transport via AQP2 fell. The vasopressin-c-AMP-axis did not mediate this effect, but it may be a consequence of the changes in the natriuretic peptide system and/or the angiotensin-aldosterone system
\end{abstract}

Trial Registration: Clinical Trials Identifier: NCT00281762.

\section{Background}

Inhibition of prostaglandin synthesis reduces renal water and sodium excretion in the kidneys, especially in patients with renal disease or heart failure. A recent study suggested that increased absorption of sodium took place in the thick ascending limb of Henle during prostaglandin inhibition [1]. However, the distal part of the nephron might also participate in this process, i. e.

\footnotetext{
* Correspondence: thomasguldager@webspeed.dk

'Department of Medical Research, Holstebro Hospital, Lægaardvej 12, 7500 Holstebro, Denmark

Full list of author information is available at the end of the article
}

by an increase in the absorption of water and sodium via the aquaporine2 water channels (AQP2) and epithelial sodium channels $(\mathrm{ENaC})$, respectively. The effect of prostaglandin inhibition on renal water and sodium excretion is most pronounced during conditions with an increased prostaglandin synthesis. During fasting, urinary concentrating and diluting ability was reduced, and AQP2 expression down regulated, possibly due to an antagonizing effect of increased prostaglandin level on the effect of vasopressin on water transport in the principal cells [2-5]. In addition, fasting induced natriuresis in man, and prostaglandin $E_{2}$ inhibited sodium 
absorption in the collecting ducts in rats and rabbits [6-8]. Thus, elevated renal levels of prostaglandin during fasting might mediate natriuresis via $\mathrm{ENaC}$ [9]. The degree of water transport via AQP2 is reflected by the level of urinary excretion of aquaporine2 (u-AQP2) [10]. Correspondingly, the sodium transport via $\mathrm{ENaC}$ is supposed to be reflected by level of urinary excretion of the $\beta$-fraction of $\mathrm{ENaC}\left(\mathrm{u}-\mathrm{ENaC}_{\beta}\right)$. This is the first report with measurement of $\mathrm{u}-\mathrm{ENaC}_{\beta}$ as a biomarker of the activity of the epithelial sodium channels in the distal tubuli.

In the present study, we measured the effect of inhibition of prostaglandins on $\mathrm{u}-\mathrm{AQP} 2$ and $\mathrm{u}-\mathrm{ENaC}_{\beta}$ during fasting. We wanted to test the hypotheses that a reduction of prostaglandin synthesis by ibuprofen treatment during fasting would 1 . Increase $\mathrm{u}-\mathrm{AQP} 2$ and $\mathrm{u}-\mathrm{ENaC}_{\beta}$ during baseline condition and change the renal response to hypertonic saline infusion, and 2 . The increased renal water and sodium absorption during ibuprofen treatment was mediated via increased transport via AQP2 and $\mathrm{ENaC}$.

We performed a randomized, placebo controlled crossover study in healthy humans during baseline condition and during hypertonic saline infusion to examine the effect of ibuprofen on renal handling of water and sodium during fasting. We measured the effect of ibuprofen/placebo on $\mathrm{u}-\mathrm{AQP} 2, \mathrm{u}-\mathrm{ENaC}_{\beta}$, fractional urinary excretion of sodium $\left(\mathrm{FE}_{\mathrm{Na}}\right)$, urinary excretion of prostaglandin $\mathrm{E}_{2}\left(\mathrm{u}-\mathrm{PGE}_{2}\right)$, urinary excretion of cyclic AMP (u-c-AMP), free water clearance $\left(\mathrm{C}_{\mathrm{H} 2 \mathrm{O}}\right)$, and plasma concentrations of renin (PRC), angiotensin II (p-Ang II), aldosterone (p-Aldo), vasopressin ( $\mathrm{p}$-AVP), atrial natriuretic peptide (p-ANP), and brain natriuretic peptide (p-BNP).

\section{Methods}

\section{Participants}

Inclusion criteria: Both males and females; age 18-65 years; body mass index $<30$. Exclusion criteria: Clinical signs or history of disease in the heart, lungs, kidneys or endocrine organs; abnormal laboratory tests (blood hemoglobin, white cell count, platelet counts, plasma concentrations of sodium, potassium, creatinine, albumine, bilirubine, alanine-aminotransferase, and cholesterol; blood glucose and albumin and glucose in urine); malignancies; arterial hypertension (i.e. casual blood pressure $>140 / 90 \mathrm{mmHg}$ ); alcohol abuse (more than 21 drinks per week for males and more than 14 for females); medical treatment; pregnancy; breast-feeding; lack of oral contraceptive treatment to women in the fertile age; intercurrent diseases; problems with blood sampling or urine collection; allergy to ibuprofen; medicine abuse; donation of blood less than 1 month before the study; and unwillingness to participate.
Withdrawal criteria: Development of one or more of the exclusion criteria.

\section{Ethics}

The Scientific Committee of Ringkøbing, Ribe and Southern Jutland Counties (j.no.2623-04) approved the study. All participants received written information and gave their consent by signature. The study was carried out in compliance with the Helsinki Declaration.

\section{Design}

The study was randomized, placebo-controlled, double blind, and over-crossed. There was a time interval of 2 weeks between the two examinations. Each examination took three days.

\section{Recruitment}

Participants were recruited by advertisements in public and private institutions.

\section{Diet and fluid intake}

The normal energy requirement was calculated with the formula: weight $(\mathrm{kg}) * 100(\mathrm{~kJ})$ * activity factor (AF). AF ranged from 1.3 to 2.4 with a possible extra of 0.3 for physical activity in the spare time, e.g. $30 \mathrm{~min}$. of sport 5-6 times a week. AF of 1.3 indicates no physical activity. AF of 1.4-1.5 indicates sedentary work without physical activity in the spare time. AF of 1.6-1.7 indicates work with walking during work hour and/or physical activity in the spare time, AF of 1.8-1.9 corresponds to shop assistant, (standing/walk all day), AF 2.0-2.4 indicates hard physical activity with or without physical activity in the spare time. The food had a specified energy amount with carbonhydrates (55\% of the total energy), protein (15\% of the total energy), and fat (30\% of the total energy). The diet contained three main meals and three small meals. The participants were not allowed to add any spices or sodium to the meals or to divide the meals into bigger or smaller portions. The participants drank tap water $35 \mathrm{~mL} / \mathrm{kg}$ each 24-hour and nothing else. They maintained normal physical activity during the study.

\section{Procedure}

Subjects were studied on three consecutive days. Table 1 shows the experimental design.

Day 1 (24 hours): The participants ate the specified diet, drank tap water $35 \mathrm{~mL} / \mathrm{kg}$ body weight, and maintained normal physical activity.

Day 2 (24 hours): The participants fasted, drank tap water $35 \mathrm{~mL} / \mathrm{kg}$ body weight maintained normal physical activity, and collected urine during 24 hours. They received a tablet of $600 \mathrm{mg}$ ibuprofen or placebo at 
Table 1 Overview of the study design

\begin{tabular}{|c|c|c|c|c|c|c|c|c|c|c|c|c|c|c|c|c|c|}
\hline \multirow[b]{2}{*}{ Time } & \multicolumn{3}{|c|}{ Day 1} & \multicolumn{3}{|c|}{ Day 2} & \multicolumn{11}{|c|}{ Examination day } \\
\hline & $\begin{array}{l}7: 00 \\
\text { AM }\end{array}$ & $\begin{array}{l}3: 00 \\
\text { PM }\end{array}$ & $\begin{array}{l}\text { 11:00 } \\
\text { PM }\end{array}$ & $\begin{array}{l}7: 00 \\
\text { AM }\end{array}$ & $\begin{array}{l}\text { 3:00 } \\
\text { PM }\end{array}$ & $\begin{array}{l}11: 00 \\
\text { PM }\end{array}$ & $\begin{array}{l}7: 00 \\
\text { AM }\end{array}$ & $\begin{array}{l}8: 00 \\
A M\end{array}$ & $\begin{array}{l}9: 00 \\
\text { AM }\end{array}$ & $\begin{array}{l}9: 30 \\
\text { AM }\end{array}$ & $\begin{array}{l}\text { 10:00 } \\
\text { AM }\end{array}$ & $\begin{array}{l}\text { 10:30 } \\
\mathrm{AM}\end{array}$ & $\begin{array}{l}11: 00 \\
\text { AM }\end{array}$ & $\begin{array}{l}11: 30 \\
\text { AM }\end{array}$ & $\begin{array}{l}12: 00 \\
\text { AM }\end{array}$ & $\begin{array}{l}12: 30 \\
\text { AM }\end{array}$ & $\begin{array}{l}13: 00 \\
\text { AM }\end{array}$ \\
\hline Food & \multicolumn{3}{|c|}{ specified diet } & \multicolumn{3}{|c|}{ Fasting } & \multicolumn{11}{|c|}{ Fasting } \\
\hline Water & \multicolumn{3}{|c|}{$\begin{array}{l}35 \mathrm{ml} / \mathrm{kg} \text { body } \\
\text { weight }\end{array}$} & \multicolumn{3}{|c|}{$\begin{array}{l}35 \mathrm{ml} / \mathrm{kg} \text { body } \\
\text { weight }\end{array}$} & \multicolumn{11}{|c|}{$175 \mathrm{ml}$ every $1 / 2$ hour } \\
\hline $\begin{array}{l}\text { Ibuprofen/ } \\
\text { placebo }\end{array}$ & & & & $x$ & $x$ & $x$ & $x$ & & & & & & & & & & \\
\hline $\begin{array}{l}\text { Urine } \\
\text { samples }\end{array}$ & & & & \multicolumn{3}{|c|}{$\begin{array}{l}24 \text { hour urine } \\
\text { collection }\end{array}$} & \multicolumn{4}{|c|}{$2 \frac{1}{2}$ hour urine collection } & \multicolumn{3}{|c|}{$\begin{array}{l}\text { Baseline urine } \\
\text { collection }\end{array}$} & 1 & 2 & 3 & 4 \\
\hline $\begin{array}{l}\text { Blood } \\
\text { samples }\end{array}$ & & & & & & & & $\uparrow$ & $\uparrow$ & $\uparrow$ & $\uparrow$ & $\uparrow$ & $\uparrow$ & $\uparrow$ & $\uparrow$ & $\uparrow$ & $\uparrow$ \\
\hline $\begin{array}{l}3 \% \text { saline } \\
\text { infusion }\end{array}$ & & & & & & & & & & & & & $\begin{array}{l}7 \mathrm{ml} / \mathrm{h} \\
\text { weigh }\end{array}$ & body & & & \\
\hline
\end{tabular}

07.00 a.m., 03.00 p.m., 11.00 p.m., and the next morning at 07.00 a.m.

Day 3: The participants arrived at 7:30 a.m. in the laboratory. An intravenous catheter was placed in fossa cubiti on each side; one for collection blood samples, the other for infusion of the ${ }^{51} \mathrm{Cr}$-EDTA and hypertonic saline. Urine was collected from 7:30-9:30 to measure the effect variables after a period of 24 hours of fasting. Afterwards, urine was collected in the following seven periods: 09:30-10:00 a.m. (P-1), 10:0010:30 a.m. (P-2), 10:30-11:00 a.m. (P-3), 11:00-11:30 a. m. (P-4), 11:30-12:00 a.m. (P-5), 12:00-12:30 p.m. (P-6) and 12:30-01:00 p.m. (P-7). Urine was analyzed for $\mathrm{u}-$ AQP-2, u-ENaC, u-Osm, u-Na, u-K, u-creat, u-cAMP, $\mathrm{u}-\mathrm{PGE}_{2}, \mathrm{u}-{ }^{51} \mathrm{Cr}-\mathrm{EDTA}$. The subjects voided in the standing or sitting position. Otherwise, they were in the supine position during the examination. Blood samples were taken every $30 \mathrm{~min}$. starting at $09.30 \mathrm{a}$. m. for analysis of $\mathrm{p}-\mathrm{AVP}, \mathrm{p}-\mathrm{Osm}, \mathrm{p}-\mathrm{K}, \mathrm{p}-\mathrm{Na}, \mathrm{p}-\mathrm{Crea}$, $\mathrm{p}$-albumin, $\mathrm{p}-{ }^{51} \mathrm{Cr}$-EDTA. In addition, blood samples for measurements of p-Ang II, p-ANP, p-BNP, p-PRC, and p-ALDO were drawn at 08.00 a.m., 11.00 a.m., 12.00 p.m., and 01.00 p.m. A total amount of $350 \mathrm{~mL}$ blood was drawn during the each study day. The blood drawn at blood sampling was immediately substituted with isotonic saline. From 11.00 a.m. to 11.30 a.m. (P-4), 3\% saline was infused, $7 \mathrm{ml} / \mathrm{kg}$ body weight. Blood pressure and pulse rate were measured every 30 min. during the examination.

The participants were weighed before (day 3 at 07:30 a.m.) and after the trial (01:30 p.m.).

\section{Effect variables}

Main effect variables were $u-A Q P 2$ and $u-E N a C$. The other effect variables were $\mathrm{u}-\mathrm{PGE}_{2}, \mathrm{u}-\mathrm{C}_{\mathrm{AMP}}, \mathrm{p}-\mathrm{AVP}$, $\mathrm{C}_{\mathrm{H} 2 \mathrm{O}}$ urine volume, $\mathrm{FE}_{\mathrm{Na}}, \mathrm{p}-\mathrm{Osm}, \mathrm{u}-\mathrm{Osm}, \mathrm{p}-\mathrm{PRC}$, p-Aldo, p-ANP, p-BNP and p-Ang II.

\section{Number of participants}

An increase in $\mathrm{u}-\mathrm{AQP} 2$ of $0.2 \mathrm{ng} / \mathrm{min}$ was considered the relevant difference between ibuprofen and placebo. The standard deviation was estimated to be $0.15 \mathrm{ng} /$ min. With a level of significance of $5 \%$ and a power of $90 \%, 14-15$ healthy subjects needed to be included in the trial.

\section{Test substance}

The Hospital Pharmacy conducted the randomization and prepared the medication. The tablets were kept in a sealed container with tablets for one day. Each tablet contained either ibuprofen $600 \mathrm{mg}$ or placebo.

\section{Measurements}

Glomerular filtration rate was measured using the constant infusion clearance technique with ${ }^{51} \mathrm{Cr}$-EDTA as a reference substance.

$U-A Q P-2$ was measured by radioimmunoassay as previously described, and antibodies were raised in rabbits to a synthetic peptide corresponding to the $15 \mathrm{COOH}$ terminal amino acids in human AQP2 to which was added an $\mathrm{NH}_{2}$-terminal cystein for conjugation and affinity purification [10]. Minimal detection level was $32 \mathrm{pg} /$ tube. The coefficients of variation were $11.7 \%$ (inter-assay) and 5.9\% (intra-assay).

$U$-c-AMP was measured using a kit obtained from $\mathrm{R} \&$ D Systems, Minneapolis, MN, USA. Minimal detection level was $12.5 \mathrm{pmol} /$ tube. The coefficients of variation were $6.9 \%$ (inter-assay) and $5.3 \%$ (intra-assay).

$E N a C_{\beta}$ was measured by a newly developed RIA. Urine samples were kept frozen at $-20^{\circ} \mathrm{C}$ until assayed. $\mathrm{ENaC}_{\beta}$ was synthesized and purchased by Lofstrand Labs Limited - Gaithersburg, Maryland, USA, see Appendix. $U-P G E_{2}$ was measured by a kit from Assay Designs, Inc., Ann Arbor, MI, USA. The coefficients of variations were $10.9 \%$ (inter-assay) and 6.3\% (intra-assay). 
Blood samples were centrifuged for 15 minutes at $3000 \mathrm{rpm}$ at $4^{\circ} \mathrm{C}$. Plasma was separated from blood cells and kept frozen at $-20^{\circ} \mathrm{C}$ until assayed. $A V P, A N P, B N P$, and Ang $I I$ were extracted from plasma with $\mathrm{C}_{18}$ SepPak (Water associates, Milford, MA, USA), and subsequently determined by radioimmunoassays $[11,12]$. The antibody against AVP was a gift from Professor Jacques Dürr, Miami, FL., USA. Minimal detection level was 0.5 $\mathrm{pmol} / \mathrm{L}$. The coefficients of variation were $13 \%$ (interassay) and 9\% (intra-assay). Rabbit anti-ANP antibody was obtained from Department of Clinical Chemistry, Bispebjerg Hospital, Denmark. Minimal detection level was $0.5 \mathrm{pmol} / \mathrm{L}$, coefficients of variation were $12 \%$ (inter-assay) and 10\% (intra-assay). Rabbit anti-BNP antibody without cross-reactivity with urodilatin and $\alpha$-ANP was used. Minimal detection level was $0.5 \mathrm{pmol} /$ $\mathrm{L}$ plasma. The coefficients of variation were $11 \%$ (interassay) and 6\% (intra-assay). The antibody against Ang II was obtained from Department of Clinical Physiology, Glostrup Hospital, Denmark. Minimal detection level was $2 \mathrm{pmol} / \mathrm{L}$. The coefficients of variation were $12 \%$ (inter-assay) and 8\% (intra-assay).

Aldosterone in plasma was determined by radioimmunoassay using a kit from Diagnostic Systems Laboratories Inc., Webster, Texas, USA. Minimal detection level was $22 \mathrm{pmol} / \mathrm{L}$. The coefficients of variations were $8.2 \%$ (inter-assay) and 3.9\% (intra-assay).

$P R C$ is determined by radioimmunoassay using a kit from CIS Bio International, Gif-Sur-Yvette Cedex, France. Minimal detection level was $1 \mathrm{pg} / \mathrm{ml}$. The coefficients of variations were $14.5 \%$ (inter-assay) and $4.5 \%$ (intra-assay).

Plasma and urinary osmolality were measured by freezing-point depression (Advanced Model 3900 multisampling osmometer).

Blood pressure was measured with UA-743 digital blood pressure meter (A\&D Company, Tokyo, Japan)

Plasma and urinary concentrations of sodium and potassium were measured by routine methods at the Department of Clinical Biochemistry, Holstebro Hospital, Denmark.

All clearances were standardized to a body surface area of $1.73 \mathrm{~m}^{2}$.

\section{Statistics}

Statistical level of significance was $\mathrm{P}<0.05$ in all analyses. We used A General Linear Model with Repeated Measures for comparison between ibuprofen treatment and placebo during fasting when several measurements were done during the examination. A paired t-test was used for comparison between two groups. Bonferroni correction was used when appropriate. Values are given as mean $\pm \mathrm{SD}$.

\section{Results}

\section{Demographics}

Twenty subjects were allocated to the study. Three participants were excluded. The first was not able to fast for 24 hours, the second needed acute medication due to an intercurrent disease, and in the third blood sampling could not be performed. Seventeen participants were included in the study, 7 women and 10 men with a mean age of $33 \pm 8$ years. Blood pressure was $124 / 72$ $\pm 14 / 9 \mathrm{mmHg}$. Blood samples showed: B-Hemoglobin $8.8 \pm 0.79 \mathrm{mmol} / \mathrm{L}, \mathrm{P}$-Sodium $139 \pm 2.4 \mathrm{mmol} / \mathrm{L}$, P-Potassium $3.8 \pm 0.3 \mathrm{mmol} / \mathrm{l}$, P-Albumin $42 \pm 1.5 \mathrm{~g} / \mathrm{L}$, P-Creatininium $78 \pm 15 \mu \mathrm{mol} / \mathrm{L}, \mathrm{P}$-Bilirubin $8 \pm$ $3 \mu \mathrm{mol} / \mathrm{L}, \mathrm{P}$-Alanintransaminase $23 \pm 9 \mathrm{U} / \mathrm{L}, \mathrm{P}$-Glucose $5.2 \pm 0.8 \mathrm{mmol} / \mathrm{L}, \mathrm{P}-$ Cholesterol $4.4 \pm 0.7 \mathrm{mmol} / \mathrm{L}$.

Effect of ibuprofen during fasting on $u-A Q P 2, u-E N a C_{\beta}$, uPGE $_{2}$, u-c-AMP, $\mathrm{C}_{\mathrm{H} 2 \mathrm{O}}$, and p-AVP

Table 2 shows the effect of fasting during a 24 hours period and during $2 \frac{1}{2}$ hours immediately after 24 hours fasting. During fasting ibuprofen reduced $\mathrm{u}-\mathrm{PGE}_{2}$ by $50 \%(\mathrm{P}<0.03), \mathrm{u}-\mathrm{AQP} 2$ by $17 \%(\mathrm{P}<0.01)$, and $\mathrm{u}-\mathrm{AQP} 2 / \mathrm{u}-\mathrm{Crea}$ by $18 \%(\mathrm{P}<0.01)$. U-ENaC $\beta$ was increased by $170 \%(\mathrm{P}<0.0001)$. We found no statistically significant changes in urine volume, $\mathrm{C}_{\mathrm{H}_{2}} \mathrm{O}$ and $\mathrm{u}$-c-AMP despite a tendency to lower values during ibuprofen treatment.

After fasting ibuprofen reduced $\mathrm{u}-\mathrm{PGE}_{2}$ by $44 \%$ ( $\mathrm{P}<$ 0.02), u-AQP2/u-Crea by $27 \%(\mathrm{P}<0.03)$, and $\mathrm{u}-\mathrm{ENaC}_{\beta}$ was increased by $210 \%(\mathrm{P}<0.0001)$ in $2 \frac{1}{2}$ hours urine collection immediately after the 24 hours fasting period. We measured no statistically significant changes in urine output, $\mathrm{C}_{\mathrm{H}_{2}} \mathrm{O}$ and $\mathrm{u}-\mathrm{c}$-AMP despite a tendency to lower values during ibuprofen treatment.

\section{Effect of ibuprofen on the response to hypertonic saline infusion}

Table 3 shows the effect variables before, during and after hypertonic saline infusion. U-AQP2, p-AVP, uOsm and p-Osm increased significantly during infusion of $3 \%$ saline. After $120 \mathrm{~min}$. U-AQP2 increased by $29 \%$ ( $\mathrm{p}<0.01)$ during ibuprofen treatment and by $51 \%$ ( $\mathrm{p}<$ 0.001 ) during placebo. The level of $\mathrm{u}-\mathrm{AQP} 2$ was significantly lower during ibuprofen treatment at three of four measurements after 3\% saline infusion. During ibuprofen treatment we found that $\mathrm{ENaC}_{\beta}$ was increased significantly and approximately 3 fold at all times during the hypertonic saline infusion (figure 1). After $60 \mathrm{~min}$ we found a modest, but significant reduction in $\mathrm{ENaC}_{\beta}$ by $12 \%$ ( $\mathrm{p}<0.001)$, and this reduction remained unchanged during the study. During placebo $\mathrm{ENaC}_{\beta}$ levels were reduced significantly at $30 \mathrm{~min}$ and again 120 after hypertonic saline infusion. P-AVP increased by 
Table 2 Effect of ibuprofen on urine volume, urinary excretion of prostaglandin E2 (U-PGE 2 ), aquaporin 2 (U-AQP2), urinary epithelial sodium channel (U-ENaC $C_{\beta}$ ), cyclic AMP (U-C-AMP), free water clearance (C H2O), serum osmolality (sOsm) and plasma arginine vasopressin (P-AVP) during 24 hours fasting and 21/2 hours period immediately after 24 hours fasting in a randomized placebo-controlled, cross over study in 17 healthy subjects

\begin{tabular}{|c|c|c|c|c|c|c|}
\hline & \multicolumn{3}{|c|}{24 hours fasting urine collection } & \multicolumn{3}{|c|}{$2 \frac{1}{2}$ hours urine collection immediately after 24 hours fasting } \\
\hline & Ibuprofen & Placebo & $\mathrm{P}$ & Ibuprofen & Placebo & $\mathrm{P}$ \\
\hline Urine volume $(\mathrm{ml})$ & $2533(718)$ & $2784(770)$ & NS & $2.75(1.39)$ & $3.30(1.56)$ & NS \\
\hline U-PGE 2 (pg/min) & $270.91(95.4)$ & $540.97(365.1)$ & 0.027 & $282(111)$ & $504(307)$ & 0.02 \\
\hline U-AQP-2 (ng/min) & $1.21(0.30)$ & $1.48(0.27)$ & 0.00016 & $3.42(2.07)$ & $4.92(3.09)$ & NS \\
\hline U-AQP-2/U-Crea (ng/umol) & $128.9(21.5)$ & $158.0(30.2)$ & 0.00002 & $0.29(0.17)$ & $0.40(0.18)$ & 0.024 \\
\hline 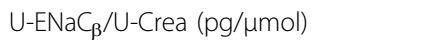 & $38.7(13)$ & $14.3(3)$ & 0.0000002 & $40.1(11)$ & $12.9(4)$ & 0.000000002 \\
\hline U-c-AMP (pmol/min) & $5737(2080)$ & $6381(3041)$ & NS & 10909 (7061) & $13762(9571)$ & NS \\
\hline $\mathrm{C}_{\mathrm{H} 2 \mathrm{O}}(\mathrm{ml} / \mathrm{min})$ & $0.029(0.47)$ & $-0.047(0.36)$ & NS & $1.30(1.40)$ & $1.85(1.29)$ & NS \\
\hline Total $\mathrm{Na}^{+}$excretion (mmol/24 hour) & $95(44)$ & $152(33)$ & 0.00001 & x & x & $x$ \\
\hline $\mathrm{FE}_{\mathrm{Na}}$ & $0.46(0.16)$ & $0.71(0.20)$ & 0.000006 & & & \\
\hline $\mathrm{S}-\mathrm{Osm}\left(\mathrm{mosm} / \mathrm{kg} \mathrm{H} \mathrm{H}_{2} \mathrm{O}\right)$ & $x$ & $x$ & $x$ & $283(2.6)$ & $284(4.1)$ & NS \\
\hline P-AVP (pmol/l) & $x$ & $x$ & $\mathrm{x}$ & $0.86(0.21)$ & $0.78(0.20)$ & NS \\
\hline
\end{tabular}

Values are means and (SD). A paired t-test was used for comparison of means.

$108 \%(\mathrm{p}<0.001)$ immediately after $3 \%$ saline infusion in the ibuprofen group and by $118 \%(\mathrm{P}<0.001)$ in the placebo group. U-Osm increased by $164 \%$ ( $\mathrm{p}<0.001$ ) immediately after $3 \%$ saline infusion in the ibuprofen group and by $157 \%(\mathrm{P}<0.001)$ in the placebo group. S-Osm increased 3\% ( $\mathrm{p}<0.001)$ immediately after $3 \%$ saline infusion in the ibuprofen group and by $2.5 \%(\mathrm{P}<$ $0.001)$ in the placebo group. The levels of P-AVP, $\mathrm{u}$-Osm and s-Osm did not differ between ibuprofen and placebo. Urine volume and $\mathrm{C}_{\mathrm{H} 2 \mathrm{O}}$ decreased by $55 \%$ (p < 0.001 ) and $105 \%$ ( $\mathrm{p}<0.001)$, respectively, during ibuprofen administration and by $57 \%(\mathrm{p}<0.001)$ and $109 \%$ $(\mathrm{p}<0.001)$ during placebo. Urine volume and $\mathrm{C}_{\mathrm{H} 2 \mathrm{O}}$ did not differ significantly between the two groups. U-PGE did not change significantly during 3\% saline infusion. The initial reduction in $\mathrm{u}-\mathrm{PGE}_{2}$ persisted during ibuprofen treatment both during and after 3\% saline infusion. GFR and u-c-AMP did not change significantly during $3 \%$ saline infusion and did not differ between ibuprofen and placebo treatment.

\section{Effect of ibuprofen on $\mathrm{FE}_{\mathrm{Na}}$ and total sodium excretion}

During 24 hours of fasting the total sodium excretion was reduced by $37 \%(\mathrm{p}<0.001)$ during Ibuprofen treatment, and $\mathrm{FE}_{\mathrm{Na}}$ was reduced by $35 \%(\mathrm{p}<0.001)$. figure 2 shows that ibuprofen reduced $\mathrm{FE}_{\mathrm{Na}}$ significantly at baseline, during and after hypertonic saline infusion. The changes after $3 \%$ saline infusion were the same in the two groups, but at different levels. $\mathrm{FE}_{\mathrm{Na}}$ at baseline was $36 \%$ ( $p=0.006$ ) higher during placebo treatment compared with ibuprofen, and this difference remaind after infusion of hypertonic saline. Urinary sodium excretion increased significantly from baseline (Placebo: $1129 \pm$ $509 \mu \mathrm{mol} / \mathrm{min}$; Ibuprofen $827 \pm 541 \mu \mathrm{mol} / \mathrm{min})$ to the level during infusion (Placebo: $2856 \pm 1068 \mu \mathrm{mol} / \mathrm{min}$; Ibuprofen $3305 \pm 941 \mu \mathrm{mol} / \mathrm{min}$ ) and in the period after infusion (Placebo: $5603 \pm 1907 \mu \mathrm{mol} / \mathrm{min}$; Ibuprofen $5978 \pm 1793 \mu \mathrm{mol} / \mathrm{min})$.

\section{Effect of ibuprofen on vasoactive hormones after 24} hours fasting and after hypertonic saline infusion Ibuprofen treatment increased p-BNP significantly during all periods of the study, except for $60 \mathrm{~min}$ after infusion (Table 4). P-BNP increased by $61 \%(\mathrm{p}<0.03)$ immediately after 24 hours of fasting by ibuprofen. At baseline (before saline infusion) p-BNP was increased by $60 \%(\mathrm{p}<0.01)$. No significant increase in $\mathrm{p}-\mathrm{BNP}$ values there observed 60 min after hypertonic saline infusion, but a clearer tendency was seen to a higher levels during ibuprofen $(\mathrm{p}<0.08)$. The increase in $\mathrm{p}-\mathrm{BNP}$ was $42 \%$ 120 min after hypertonic saline infusion $(\mathrm{p}<0.02)$. P-ANP tended to increase using A General Linear Model With Repeated Measurements ( $\mathrm{p}<0.055)$. At baseline, P-ANP increased by $29 \%(\mathrm{p}<0.03)$, and $60 \mathrm{~min}$ after hypertonic saline infusion the increase was $20 \%$ ( $\mathrm{p}<0.03$ ). No significant difference was observed $120 \mathrm{~min}$ after hypertonic saline infusion. Both p-Ang II and p-aldo tended to fall during ibuprofen treatment.

\section{Effect of ibuprofen on blood pressure}

At baseline blood pressure was 115/64 $\pm 9 / 8 \mathrm{mmHg}$ and pulse rate was $57 \pm 8$ beats/min during Ibuprofen treatment. The corresponding values during placebo did not deviate significantly, blood pressure was114/65 \pm 11/7 $\mathrm{mmHg}$ and pulse rate $56 \pm 7$ beats $/ \mathrm{min}$.

The response to $3 \%$ saline infusion was measured 30 min after infusion. Systolic blood pressure was unchanged during ibuprofen treatment and increased by $4 \mathrm{mmHg}$ 
Table 3 Urinary aquaporin-2 creatinine adjusted (U-AQP2/u-crea), urinary epithelial $\mathrm{Na}^{+}$channel (U-ENaC $\left.\beta / \mathrm{u}-\mathrm{crea}\right)$, plasma arginine vasopressin (AVP), urine osmolality (U-OSM), serum osmolality (S-OSM), urinary excretion of prostaglandin2 (U-PGE2), free water clearance (CH2O), urinary excretion of CAMP (U-CAMP), and Glomerular filtration rate (GFR)

\begin{tabular}{|c|c|c|c|c|c|c|c|}
\hline & & Baseline & $30 \mathrm{~min}$ & $60 \mathrm{~min}$ & $90 \mathrm{~min}$ & 120 & $\mathbf{P}$ \\
\hline \multicolumn{8}{|l|}{ U-AQP2/u-crea (ng/umol) } \\
\hline & Placebo & 154(33) & $189(69) * *$ & $200(61) * * *$ & $225(75) * * *$ & $233(76) * * *$ & 0.005 \\
\hline & Ibuprofen & $161(25)$ & $161(62)$ & $202(68)^{*}$ & $199(52)^{* *}$ & $208(64)^{* *}$ & \\
\hline & P-value & NS & 0.036 & NS & 0.008 & 0.014 & \\
\hline \multirow[t]{3}{*}{ U-EnaC/u-crea (pg/umol) } & Placebo & $11.6(3)$ & $13.4(3) * *$ & $12.8(4)$ & $13.4(4)$ & $13.7(4) * *$ & $<0.0001$ \\
\hline & Ibuprofen & $44.8(13)$ & $44.1(10)$ & $38.6(10) * *$ & $39.1(10) * *$ & $35.8(9) * * *$ & \\
\hline & P-Value & $<0.0001$ & $<0.0001$ & $<0.0001$ & $<0.0001$ & $<0.0001$ & \\
\hline \multicolumn{8}{|l|}{ P-AVP (pg/ml) } \\
\hline & Placebo & $0.87(0.5)$ & $1.9(0.13) * * *$ & $1.5(0.12) * * *$ & $1.3(0.13) * * *$ & $1.2(0.9) * * *$ & NS \\
\hline & Ibuprofen & $0.91(0.5)$ & $1.9(0.15) * * *$ & $1.5(0.11) * * *$ & $1.4(0.10) * * *$ & $1.2(0.9) * * *$ & \\
\hline \multicolumn{8}{|l|}{ U-OSM (mosm/kg H2O) } \\
\hline & Placebo & $130(25)$ & $335(77) * * *$ & $588(113) * * *$ & $585(11) * * *$ & $566(110) * * *$ & NS \\
\hline & Ibuprofen & $125(31)$ & $331(107) * * *$ & $631(201) * * *$ & $625(119) * * *$ & $612(130) * * *$ & \\
\hline \multicolumn{8}{|l|}{ S-OSM (mosm/kg H2O) } \\
\hline & Placebo & $283(2.7)$ & $291(4.1) * * *$ & $290(3.2) * * *$ & $289(3.6) * * *$ & $287(3.7) * * *$ & NS \\
\hline & Ibuprofen & $283(3.0)$ & $293(3.7)^{* * *}$ & $291(2.6) * * *$ & $289(3.2) * * *$ & $287(3.5)^{* * *}$ & \\
\hline \multicolumn{8}{|l|}{ U-PGE2 (pg/min) } \\
\hline & Placebo & $281(123)$ & 212(105) & 256(118) & 293(133) & 298(173) & $<0.001$ \\
\hline & Ibuprofen & $507(341)$ & $385(180)$ & $415(138)$ & $406(160)$ & $507(411)$ & \\
\hline & P-Value & 0.02 & 0.001 & 0.0004 & 0.005 & 0.02 & \\
\hline \multicolumn{8}{|l|}{$\mathrm{CH} 2 \mathrm{O}(\mathrm{ml} / \mathrm{min})$} \\
\hline & Placebo & $4.05(1.2)$ & $-0.38(0.5) * * *$ & $-1.60(0.6) * * *$ & $-2.00(0.7) * * *$ & $-2.00(0.7) * * *$ & NS \\
\hline & Ibuprofen & $3.70(1.4)$ & $-0.20(1.0) * * *$ & $-1.62(0.8) * * *$ & $-1.92(0.7) * * *$ & $-2.00(0.7) * * *$ & \\
\hline \multirow[t]{3}{*}{ Urine $(\mathrm{ml} / \mathrm{min})$} & Placebo & $7.02(1.57)$ & $3.0(0.19)^{* * *}$ & $1.8(0.20)^{* * *}$ & $2.16(0.20)^{* * *}$ & $2.3(0.20)^{* * *}$ & $<0.0001$ \\
\hline & Ibuprofen & $6.31(1.71)$ & $2.8(0.23)^{* * *}$ & $1.6(0.12)^{* * *}$ & $1.7(0.11)^{* * *}$ & $1.9(0.13)^{* * *}$ & \\
\hline & P-Value & NS & NS & NS & 0.016 & NS & \\
\hline \multicolumn{8}{|l|}{ U-CAMP (pmol/min) } \\
\hline & Placebo & $3819(1034)$ & $3974(1251)$ & 4285(1387) & 4114(1353) & $4219(1125)$ & NS \\
\hline & Ibuprofen & $4016(1180)$ & 3738(759) & $4447(1243)$ & $4196(1248)$ & 4377(1136) & \\
\hline \multicolumn{8}{|l|}{ GFR (ml/min) } \\
\hline & Placebo & $98(12)$ & $94(16)$ & $94(21)$ & $103(21)$ & $102(17)$ & NS \\
\hline & Ibuprofen & $98(13)$ & $93(18)$ & $98(15)$ & $101(16)$ & 103(12) & \\
\hline
\end{tabular}

Baseline values before hypertonic saline infusion, 30, 60, 90 and $120 \mathrm{~min}$ after hypertonic saline infusion in 17 healthy humans administered with ibuprofen or placebo.

Values are means and (SD). P indicates significant difference between ibuprofen treatment and placebo using a General Linear Model With Repeated Measures. A paired t-test was used for comparison of means, when differences were found between the two treatments. *indicated a statistical significant changed from baseline values* $P<0.05 * * P<0.01$, *** $P<0.001$. (longitudinal comparison).

( $\mathrm{p}<0.01)$ during placebo. Pulse rate increased by 11 beats/ $\min (\mathrm{p}<0.01)$ during ibuprofen treatment and 9 beats/ $\min (\mathrm{p}<0.01)$ during placebo. Diastolic blood pressure decreased by $2 \mathrm{mmHg}(\mathrm{p}<0.05)$ during ibuprofen treatment and were unchanged during placebo.

The response to $3 \%$ saline infusion was measured 60 min after infusion. Systolic blood pressure was unchanged during both ibuprofen and placebo treatment. Pulse rate was significantly increased in both groups by 7 Beats/min $(\mathrm{p}<0.01)$ during ibuprofen and
6 beat $/ \mathrm{min}(\mathrm{p}<0.01)$ during placebo. Diastolic blood pressure was decreased in both groups $(\mathrm{p}<0.05)$. There were no statistical differences in blood pressure and pulse rate between ibuprofen and placebo at baseline, during and after $3 \%$ saline infusion.

\section{Effect of ibuprofen and fasting on body weight and p-albumin}

Body weight were $77.6 \mathrm{~kg}$ in the placebo group and 78.1 $\mathrm{kg}$ in the ibuprofen group $(\mathrm{P}<0.07)$ after the study day, 


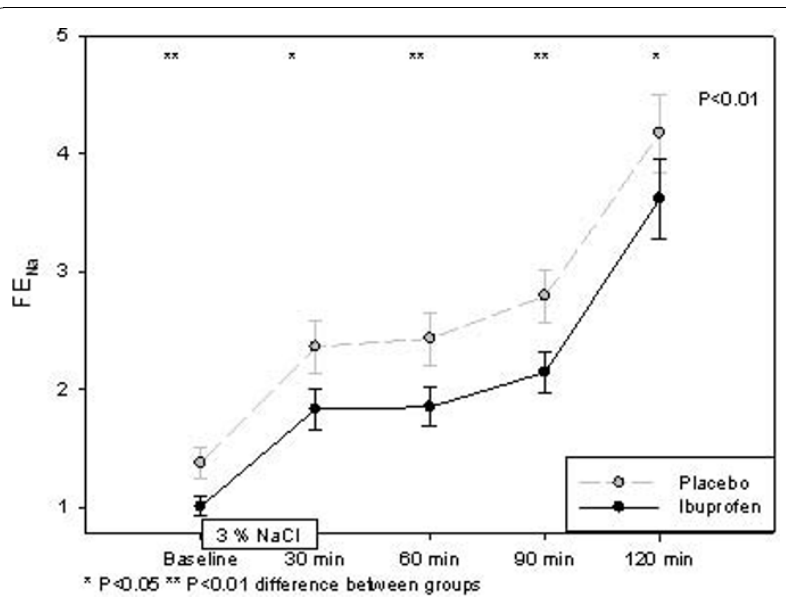

Figure 1 Effect hypertonic saline infusion on $\mathrm{ENaCb} / \mathrm{crea}$ in a randomized placebo-controlled, cross-over study of 17 healthy subjects.

at the same time there was a decrease in p-albumin from $41 \mathrm{~g} / \mathrm{l}$ at baseline to $37 \mathrm{~g} / \mathrm{l}(\mathrm{p}<0.001)$ at the end of the study. None of the subjects had edema after infusion of $3 \%$ sodium chloride.

\section{Discussion}

The present study of healthy subjects showed that ibuprofen decreased $\mathrm{FE}_{\mathrm{Na}}$ and increased $\mathrm{u}-\mathrm{ENaC}_{\beta}$ both during a 24 hours fasting period, during the first two hours after 24 hours fasting, and during the following period with hypertonic saline infusion. The increased tubular sodium absorption during ibuprofen treatment might be attributed to increased sodium transport from the tubular lumen via the epithelial sodium channels. Our hypothesis was not falsified regarding this point. However, ibuprofen decreased $\mathrm{u}-\mathrm{AQP} 2$ and $\mathrm{u}-\mathrm{PGE}_{2}$, and did

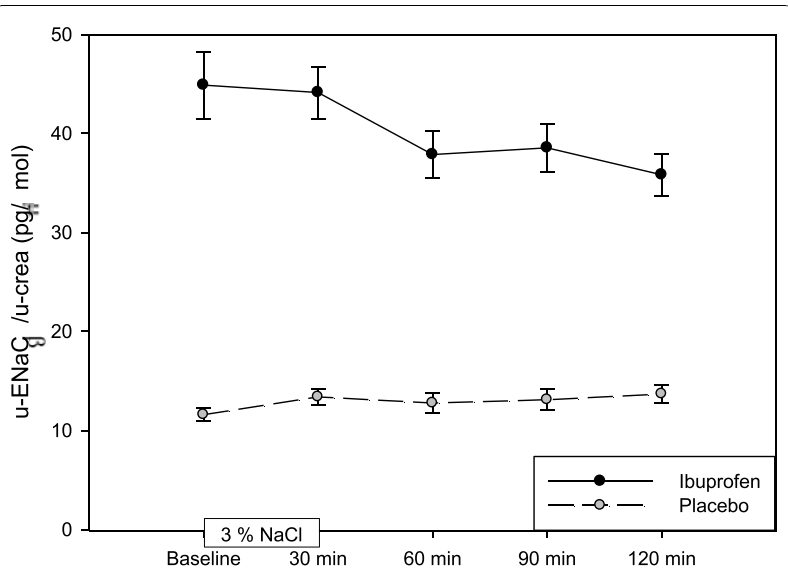

Figure 2 Effect hypertonic saline infusion on fractional sodium excretion (FENa) in a randomized placebo-controlled, crossover study of 17 healthy subjects. not change p-AVP, u-c-AMP, urinary output, and free water clearance during any of the study periods. Thus, our results demonstrated that $\mathrm{u}-\mathrm{AQP} 2$ was reduced, although an increased AQP2 trafficking might be expected, when the antagonizing effect of prostaglandins on the vasopressin mediated effect on the principal cells was reduced/eliminated during ibuprofen treatment. Consequently, our hypothesis that reduction of prostaglandin synthesis would increase u-AQP2 was falsified.

In the present study we have used a new and original method to evaluate sodium reabsorption in the principal cells in the distal tubules using a radioimmunoassay of the $\beta$-fraction of the protein in the epithelial sodium channel. The amount of $\mathrm{ENaC}_{\beta}$ in urine is supposed to reflect the activity of sodium transport via the epithelial sodium channels just as $\mathrm{u}$-AQP2 reflects the functional status of the AQP2 water channels (31). Our analyses showed that the assay has a satisfactory reliability. In addition, we demonstrated a significant correlation between changes in urinary sodium excretion and changes in $\mathrm{u}-\mathrm{ENaC}_{\beta}$. Thus, our results are in accordance with $\mathrm{u}-\mathrm{ENaC}_{\beta}$ being a biomarker of the transport of sodium via $\mathrm{ENaC}$ during acute studies, presumably reflecting up- and down regulation $\beta-\mathrm{ENaC}$ expression and sodium transport via $\mathrm{ENaC}$. It is well known that ibuprofen reduces renal sodium excretion. Our study adds new information, since our data might suggest that prostaglandin inhibition possibly reduce renal sodium excretion via an increased transport through $\mathrm{ENaC}$.

In our study, ibuprofen significantly reduced $\mathrm{FE}_{\mathrm{Na}}$ during all parts of study to a level around 35\% lower than placebo. The response in $\mathrm{FE}_{\mathrm{Na}}$ during hypertonic saline infusion was the same during treatment with ibuprofen and placebo, and the difference, i.e. the lower level of $\mathrm{FE}_{\mathrm{Na}}$ during ibuprofen treatment, persisted during the infusion. Several animal studies have shown that $\mathrm{PGE}_{2}$ has a direct inhibitory effect on sodium chloride transport in the collecting ducts $[2,5,13,14]$. In rats, this is regulated by the EP2 receptor[15]. We found that $u$ $\mathrm{ENaC}_{\beta}$ was significantly increased during ibuprofen treatment. Thus, the decrease in $\mathrm{FE}_{\mathrm{Na}}$ might, at least partly, be explained by an increased transport of sodium from the tubular lumen via $\mathrm{ENaC}$. However, we cannot exclude that the antinatriuretic effect of ibuprofen was also attributed to some extent by an upregulation of the $\mathrm{Na}-\mathrm{K}-2 \mathrm{Cl}$ cotransporter in the ascending limb of Henle's loop [16]. U-ENaC $\mathrm{C}_{\beta}$ was increased by ibuprofen without an increase in either $\mathrm{p}$-AVP or u-c-AMP, which indicates that AVP does not seem to play a direct regulatory role in the increased $\mathrm{u}-\mathrm{ENaC}_{\beta}$. However, the marked reduction in $\mathrm{u}-\mathrm{PGE}_{2}$ makes it likely that the reduced prostaglandin level results in the increase sodium transport via $\mathrm{ENaC}$, and this explanation is supported by evidence from animal studies [7,17-19]. 
Table 4 Effect of Ibuprofen on plasma atrial natriuretic peptide (p-ANP), plasma brain natriuretic peptide (p-BNP), plasma angiotensin II (p-AngII) and p-aldosterone (p-Aldo) at morning after 24 hours of fasting (morning), before hypertonic saline infusion (baseline), $60 \mathrm{~min}$. after hypertonic saline infusion (60 min. post) and $120 \mathrm{~min}$. after hypertonic saline infusion (120 min. post) compared with placebo in a randomized clinical trial with17 healthy subjects

\begin{tabular}{|c|c|c|c|c|c|c|}
\hline & & Morning & Baseline & 60 min. post. & 120 min. post. & $P$ \\
\hline \multicolumn{7}{|l|}{ p-ANP (pmol/l) } \\
\hline & Placebo & $5.95(3.37)$ & $5.75(2.68)$ & $9.84(3.89)$ & $8.39(4.03)$ & NS \\
\hline & Ibuprofen & $6.80(3.22)$ & $7.44(3.46)$ & $11.85(5.54)$ & 9.13 (3.78) & \\
\hline \multicolumn{7}{|l|}{ p-BNP (pmol/l) } \\
\hline & Placebo & $1.59(1.10)$ & $1.65(0.99)$ & $2.66(2.26)$ & $2.17(1.55)$ & 0.015 \\
\hline & Ibuprofen & $2.57(2.08)$ & $2.65(2.03)$ & $3.44(3.27)$ & 3.09 (2.38) & \\
\hline & $p$-value & 0.025 & 0.004 & NS & 0.015 & \\
\hline \multicolumn{7}{|l|}{$\mathrm{p}$-Renin (mU/l) } \\
\hline & Placebo & $10.1(5.3)$ & $12.2(7.8)$ & $9.5(14.7)$ & $5.5(2.1)$ & NS \\
\hline & Ibuprofen & $10.7(12.3)$ & 13.6(22.1) & $12.5(21.3)$ & $4.9(2.5)$ & \\
\hline \multicolumn{7}{|l|}{ p-Angll(pmol/l } \\
\hline & Placebo & $8.2(3.0)$ & $10.5(5.9)$ & $6.5(4.4)$ & $6.2(3.5)$ & NS \\
\hline & Ibuprofen & $7.1(3.4)$ & $7.6(4.6)$ & $5.9(4.0)$ & $5.2(2.7)$ & \\
\hline \multicolumn{7}{|l|}{ p-Aldo (pmol/l) } \\
\hline & Placebo & 310.8 (211.6) & $230.4(145.5)$ & $164.7(63.0)$ & $162.4(57.1)$ & NS \\
\hline & Ibuprofen & $293.9(137.6)$ & $190.9(55.6)$ & $156.6(27.3)$ & $161.6(36.6)$ & \\
\hline
\end{tabular}

Values are means and (SD). P indicates significant difference between ibuprofen treatment and placebo using a General Linear Model With Repeated Measures. A paired t-test was used for comparison of means, when differences were found between the two treatments.

Ibuprofen did not change the response in the effect variables qualitatively during hypertonic saline infusion, but renal sodium excretion was reduced as hypothesized. After hypertonic saline infusion $\mathrm{u}-\mathrm{ENaC}$ was reduced significantly at 60 minutes, and at the same time p-ANP tended to increase. An increase in ANP might be responsible for reduction in $\mathrm{u}-\mathrm{ENaC}_{\beta}$ during this condition, and could be seen as a homeostatic mechanism to prevent sodium and fluid expansion [6]. Aldosterone is an important regulator of the transport activity via $\mathrm{ENaC}$. Aldosterone stimulates the $\mathrm{MR}$ receptor. The result is an increased transcription of genes, which code for proteins involved in sodium transport, i. e. $\mathrm{ENaC}$ and $\mathrm{Na}-\mathrm{K}$-ATPase [3,20]. In-vitro and in-vivo studies have shown that aldosterone increases the synthesis of the $\alpha$-fraction of $\mathrm{ENaC}$ in the distal tubuli [21].

In our study, we found that $\mathrm{u}-\mathrm{ENaC} \beta$ was reduced in the ibuprofen group during and after hypertonic saline infusion. We did not measure a reduction in p-aldosterone. This might be due to the fact that our study was too short to allow the regulatory effect of aldosterone.

A time delay in aldosterone secretion has previously been demonstrated in another study, in which an acute infusion of hypertonic saline infusion decreased PRA, but plasma aldosterone was unchanged [22]. We think the short observation time after the hypertonic saline infusion might explain the fact that $\mathrm{p}$-aldosterone was unchanged in the present study.
During placebo treatment, hypertonic saline resulted in a significant increase in $\mathrm{u}-\mathrm{ENaC} \beta$. This increase was associated with an increased $\mathrm{FE}_{\mathrm{Na}}$. The explanation of this phenomenon is not clear for the time being. A considerably decrease in the renal sodium absorption more proximally in the nephron might be compensated for by an increase in absorption in the distal part of the nephron, but additional studies are required to determine the precise use of $\mathrm{u}-\mathrm{ENaC} \beta$ as biomarker for $\mathrm{ENaC}$ activity during these conditions. However, a rise in the intracellular sodium concentration was suggested to be a trigger for the feedback inhibition of sodium absorption via $\mathrm{ENaC}$ in rats when expressed in xenopus laevis oocytes [23]. Thus, the reduction in $\mathrm{u}-\mathrm{ENaC}_{\beta}$ during sodium loading could alternatively be attributed to this inhibitory feedback mechanism of increased intracellular sodium on sodium transport via $\mathrm{ENaC}$.

In a previous study, we showed that fasting decreased $\mathrm{u}-\mathrm{AQP} 2$ and reduced the stimulating effect of vasopressin on u-AQP2 [24]. Fasting increased prostaglandin synthesis, and the refractoriness to vasopressin during fasting was proposed to be due to an antagonizing effect of prostaglandins on AQP2 trafficking. Thus, it would be reasonable to hypothesize that an increase in u-AQP2 could be expected by ibuprofen treatment. On the contrary, ibuprofen reduced $\mathrm{u}-\mathrm{PGE}_{2}$ markedly in the present study during all conditions i.e. in 24 hours urine, in the period shortly after 24 hours of fasting, and 
during infusion of hypertonic saline, as expected. However, ibuprofen also reduced $\mathrm{u}-\mathrm{AQP} 2$ during all parts of the study, and thereby falsified our hypothesis that reduction of prostaglandin synthesis would increase $u$ AQP2.

A previous study in humans showed that prostacyclin infusion increased u-AQP2 excretion, and this seems to be in agreement with our results [25]. Apparently, a discrepancy exists between animal studies on the one hand and studies in man on the other. In animals, prostaglandin decreased APQ2 trafficking [2,26], and inhibition of prostaglandin synthesis by infusion of indomethacin increased urinary excretion of AQP2 [4]. In healthy man prostaglandin and prostaglandin-inhibitors had the opposite effects, as demonstrated in the present study and by others [25]

We found that ibuprofen significantly reduced $\mathrm{u}-\mathrm{PGE}_{2}$ due to a reduced renal prostaglandin synthesis. This is in accordance with other studies in healthy man $[27,28]$. Prostaglandin $\mathrm{E}_{2}$ increased urinary output and sodium excretion by inhibition of AVP stimulated water absorption, inhibition of sodium absorption and stimulation of basal water absorption [8]. Different subtypes of prostaglandin receptors mediate this effect from the basolateral part of the tubular cells [29]. Receptor stimulation by $\mathrm{PGE}_{2}$ reduced sodium reabsorption in the thick ascending limb of Henle and in the cortical collecting duct, and reduced AVP-induced water absorption in cortical collecting duct $[9,30,31]$. Both p-AVP and $\mathrm{u}$-c-AMP were unchanged by ibuprofen, but simultaneously we measured a clear reduction in $u-A Q P 2$. Thus, the vasopressin-c-AMP axis was not involved in the reduction in $\mathrm{u}-\mathrm{AQP} 2$. It is generally accepted that prostaglandin $\mathrm{E}_{2}$ antagonizes the effect of vasopressin on AQP2 trafficking via the $\mathrm{EP}_{3}$ receptor. Activation of this receptor inhibits adenylyl-cyclase, reduces the level of c-AMP, causing increased urinary output. However, the close relationship between c-AMP production and increased AQP2 trafficking was challenged in a recent experimental study [32]. Activation of the EP3 receptor inhibited AQP2 trafficking in inner medullary cells from rats, despite high levels of c-AMP, probably due to an cAMP- and $\mathrm{Ca} 2+$-independent Rho activation. Rho promotes the formation F-actin which hinders AQP2 coated vesicles reaching the apical membrane [32]. Our study in healthy man is in agreement with these findings, in the sense that we found a reduction in $\mathrm{u}-\mathrm{AQP} 2$ excretion without changes in urinary excretion of cAMP. This suggests that adenylyl cyclase activity did not contribute to our results regarding $\mathrm{u}-\mathrm{AQP} 2$ excretion. The changes in $\mathrm{p}-\mathrm{AVP}$ during hypertonic saline infusion was as expected, and the changes were not significantly different during ibuprofen treatment compared with placebo.
As expected, we measured a marked reduction in urinary sodium excretion during ibuprofen treatment as reflected in the decrease in $\mathrm{FE}_{\mathrm{Na}}$, but no significant changes in urinary output and free water clearance. However, some tubular reabsorption of water must take place simultaneously with sodium reabsorption due to the effect of ibuprofen on basal renal water transport. Most likely, this fact explains our findings, i.e. the lack of increase in urinary output and free water clearance despite decreased u-AQP2 during ibuprofen treatment. Both p-AVP and u-c-AMP were unchanged by ibuprofen, but simultaneously we measured a clear reduction in $\mathrm{u}$-AQP2. Thus, the vasopressin-c-AMP axis was not involved in the reduction in $\mathrm{u}-\mathrm{AQP} 2$. The changes in p-AVP during hypertonic saline infusion was as expected, and the changes were not significantly different during ibuprofen treatment compared with placebo.

However, other regulatory factors than vasopressin and prostaglandins may influences the expression of AQP2 and u-AQP2 such as the renin-angiotensin-aldosterone system, the natriuretic peptide system, and the sympathetic nervous system [1,6,33-38]. We measured higher levels of $\mathrm{p}$-BNP and a clear tendency to an increase in p-ANP simultaneous with a tendency to a lower level of p-Ang II and p-Aldo during ibuprofen treatment. Most likely, these changes in hormones with both vasoactive- and sodium- and water regulating properties are secondary to the sodium retention induced by ibuprofen. This is supported by the fact that p-albumin fell significantly, and that body weight tended to increase, presumably due to an expansion of the extracellular fluid volume. Animal studies support this explanation. Angiotensin II stimulated/enhanced AQP2 expression [36,38], and angiotensin II receptor blockade reduced AQP2 expression [1]. Aldosterone agonism and antagonism increased and decreased AQP2 expression, respectively [34]. We suggest that the tendency to reduced levels of the components in the renin-angiotensin-aldosterone system contributes to the reduced level of $\mathrm{u}-\mathrm{AQP} 2$ during ibuprofen treatment in fasting healthy humans.

The role of ANP in the regulation of intracellular distribution of AQP2 was addressed in rats [6]. ANPinfusion had no immediate effect on the intracellular localization of AQP2, but after 90 minutes of ANPinfusion an increased apical targeting of AQP2 was noted. This was regarded as either a direct or compensatory effect to volume depletion to avoid dehydration. A human study with head out water immersion demonstrated increased AQP2 expression accompanied by an increase in $\mathrm{p}$-ANP [33]. These findings do not prove any causal relationship, as several other homeostatic systems as the sympathetic nervous system and the renin-angiotensin-aldosterone system are also influenced 
by the intervention. Thus, the effect of the natriuretic peptide system on AQP2 trafficking and urinary excretion is not fully elucidated. Accordingly, we cannot rule out that the increased levels of the natriuretic peptides after ibuprofen treatment had modulated u-AQP2 in our study.

Inhibition of the renal prostaglandin synthesis might be dangerous in patients with heart failure, lever disease and renal insufficiency. It can result in sodium and water retention and hypertension. We did not measure any changes in blood pressure and the increase in body weight was marginal. Most like, this can be attributed to the fact that we studied healthy subjects.

\section{Conclusions}

In conclusion, ibuprofen decreased urinary sodium excretion considerably in healthy man during fasting, a state with an increased prostaglandin synthesis. During the reduced prostaglandin synthesis $\mathrm{u}-\mathrm{ENaC}_{\beta}$ was markedly increased. Our results suggest that prostaglandins have an important direct regulatory function on $\mathrm{ENaC}$ trafficking. During hypertonic saline infusion, angiotensin II and aldosterone tended to decrease in plasma and the natriuretic peptides increased, which presumably can be seen as compensatory phenomena to prevent extracellular fluid expansion. Surprisingly, ibuprofen also decreased urinary u-AQP2 both during 24 hours of fasting and during hypertonic saline infusion. This effect was not mediated via the vasopressin-c-AMP-axis, but may be mediated by the changes in the natriuretic peptide system and/or the angiotensin-aldosterone system.

\section{Appendix}

Description of the u-ENaC $C_{\beta}$ analysis, $E N a C_{\beta}$ was measured by a newly developed RIA. Urine samples were kept frozen at $-20^{\circ} \mathrm{C}$ until assayed. $\mathrm{ENaC}_{\beta}$ was synthesized and and purchased by Lofstrand Labs Limited Gaithersburg, Maryland, USA.

The $\beta-\mathrm{ENaC}$ antibody was raised against a synthethic peptide in rabbits and affinity purified as previously described [39] Iodination of $\mathrm{ENaC}_{\beta}$ was performed by the chloramine $\mathrm{T}$ method using $40 \mu \mathrm{g}$ of $\mathrm{ENaC}_{\beta}$ and 37 $\mathrm{MBq}{ }^{125} \mathrm{I}$. The reaction was stopped by addition of $20 \%$ human serum albumin. ${ }^{125}$ I-labeled $\mathrm{ENaC}_{\beta}$ was separated from the iodination mixture by the use of a Sephadex G-25 Fine column. The assay buffer was $40 \mathrm{mM}$ sodium phosphate $(\mathrm{pH}=7.4), 0.2 \%$ human albumin, $0.1 \%$ Triton X-100, and $0.4 \%$ EDTA. A $1.5 \%$ solution of gamma globulins from pig (Sigma) and $25 \%$ polyethylene glycol 6000 (Merck) also containing 0.625\% Tween 20 (Merck) was prepared using the $0.4 \mathrm{M}$ phosphate buffer. Urine samples were kept frozen at $-20^{\circ} \mathrm{C}$. After thawing out urine samples were centrifuged for $5 \mathrm{~min}$ at $1.6 \times 100 g(3,000 \mathrm{rpm})$. The supernatant was extracted using Sep-pak $\mathrm{C}_{18}$. The eluation fluid was $4 \mathrm{ml}$ of a mixture comprising $90 \%$ methanol, $0.5 \%$ acetic acid and 9.5\% demineralized water. The eluates were freeze-dried and kept at $-20^{\circ} \mathrm{C}$ until assayed. The mixture of $300 \mu \mathrm{l}$ of standard or freeze-dried urine eluates redissolved in $300 \mu \mathrm{l}$ assay buffer and $50 \mu \mathrm{l}$ of antibody was incubated for $24 \mathrm{~h}$ at $4^{\circ} \mathrm{C}$. Thereafter, $50 \mu \mathrm{l}$ of the tracer were added, and the mixture was incubated for a further $24 \mathrm{~h}$ at $4^{\circ} \mathrm{C}$. Gamma globulin from pigs $(100 \mu \mathrm{l})$ and $2 \mathrm{ml}$ polyethylene glycol 6000 were added. The mixture was centrifuged at $3,500 \mathrm{rpm}$ for $20 \mathrm{~min}$ at $4^{\circ} \mathrm{C}$. The supernatant (free fraction) was poured off, and the precipitate (bound fraction) was counted in a gamma counter. The unknown content in urine extracts was read from a standard curve. For 13 consecutive standard curves, the zero standard was $70 \pm 1.6 \%$, and for increasing amounts of $\mathrm{ENaC}_{\beta}$ standard the binding inhibition was: $69 \pm 1.4 \%$ (15.6 pg/tube), $66 \pm 1.5 \%$ (31.25 pg/tube), 62 $\pm 1.6 \%$ (62.5 pg/tube), $54 \pm 1.5 \%$ (125 pg/tube), $40 \pm$ $1.4 \%$ ( $250 \mathrm{pg} /$ tube), $26 \pm 1.2 \%$ (500 pg/tube), $14 \pm 0.6 \%$ (1000 pg/tube), $8.2 \pm 0.4 \%$ (2000 pg/tube), and $5.1 \pm$ $0.3 \%$ ( $4000 \mathrm{pg} /$ tube). The ID 50, i.e. the concentration of standard needed for $50 \%$ binding inhibition was 322 $\pm 12 \mathrm{pg} /$ tube $(\mathrm{n}=13)$. The nonspecific binding determined by performing the RIA without antibody was 1.3 $\pm 0.3 \%(\mathrm{n}=13)$. The inter-assay variation was determined by quality controls from the same urine pool spiked with $\mathrm{ENaC}_{\beta}$ standard. In consecutive assays the coefficient of variation was: at a mean level of $78 \mathrm{pg} /$ tube $12 \%$ (12 assays), at a mean level of $155 \mathrm{pg} /$ tube $10 \%$ (12 assays), and at a mean level of $394 \mathrm{pg} /$ tube $17 \%$ (10 assays). The intra-assay variation was determined on samples from the same urine pool in several assays at different concentration levels. At a mean level of 180 $\mathrm{pg} /$ tube $(n=10)$ and $406 \mathrm{pg} /$ tube $(\mathrm{n}=10)$, the coefficients of variation were $6.4 \%$ and $9.0 \%$, respectively. In addition, coefficients of variation were calculated on the basis of duplicate determinations in different assays to 9.1\% $(\mathrm{n}=22)$ in the range $58-101 \mathrm{pg} / \mathrm{tube}, 8.6 \%(\mathrm{n}=$ $26)$ in the range $143-203 \mathrm{pg} /$ tube, $8.7 \%(\mathrm{n}=20)$ in the range $205-421 \mathrm{pg} /$ tube, and $10.0 \%(\mathrm{n}=68)$ in the whole range $58-421 \mathrm{pg} /$ tube. The sensitivity calculated as the smallest detectable difference at the $95 \%$ confidence limit was $10 \mathrm{pg} /$ tube in the range $58-101 \mathrm{pg} /$ tube $(\mathrm{n}=$ $22), 20 \mathrm{pg} /$ tube in the range $143-203 \mathrm{pg} /$ tube $(\mathrm{n}=26)$, $48 \mathrm{pg} / \mathrm{tube}$ in the range $205-421 \mathrm{pg} / \mathrm{tube}(\mathrm{n}=20)$, and $28 \mathrm{pg} /$ tube in the whole range 58-421 pg/tube $(\mathrm{n}=68)$. The lower detectable limit of the assay was $34 \mathrm{pg} /$ tube. It was calculated using the average zero binding for 13 consecutive assays minus $2 \mathrm{SD}$. The volume of urine used for extraction from the same pool was varied (18 different volumes in the range 250-6000 $\mu \mathrm{l}$ ), and the mean concentration measured was $89 \pm 6 \mathrm{pg} / \mathrm{ml}$. There was a highly significant correlation between the 
extracted volume of urine and the amount of $\mathrm{pg} /$ tube $(\mathrm{r}=0.99, \mathrm{n}=18)$. Recovery of the labeled tracer during the extraction-freezing drying procedure was $94 \pm 3 \%$ $(\mathrm{n}=13), 95 \pm 3 \%(\mathrm{n}=13), 95 \pm 2 \%(\mathrm{n}=10)$, and $95 \pm$ $2 \%(n=7)$ in four different pools used in several extraction procedures. When $\mathrm{ENaC}_{\beta}$ in the range 62.5 to 250 pg was added to urine, a highly significant correlation was found between the measured and the expected values $(\mathrm{r}=0.981, \mathrm{n}=12, \mathrm{P}<0.001)$. We measured $\mathrm{u}-\mathrm{ENaC}_{\beta}$ in 9 patients with arterial hypertension treated with amiloride. During the study day, patients collected a urine sample at 08.00 and 11.00 . They took no medication in the morning before the first urine sample. Immediately after the first urine sampling, the patients took their usually dosis of amiloride 5 or $10 \mathrm{mg}$. For the whole group a significant correlation was found between the changes in $\mathrm{u}-\mathrm{Na} / \mathrm{Crea}$ and changes in $\mathrm{u}-\mathrm{ENaC}_{\beta} /$ crea ( $\rho=-0.720, \mathrm{n}=9, \mathrm{P}=0.029)$.

\section{Acknowledgements}

We thank laboratory technicians Lisbeth Mikkelsen, Henriette Vorup Simonsen, Kirsten Nyborg and Anne Mette Ravn for skilful technical assistance and commitment, catering officer and the staff at the kitchen for making the diet, and The Hospital Pharmacy for randomizing and preparation of the study drug.

The trial was supported by grant from Ringkjobing County, Lundbeck Foundation and Hoerslev Foundation.

\section{Author details}

'Department of Medical Research, Holstebro Hospital, Lægaardvej 12, 7500 Holstebro, Denmark. ${ }^{2}$ University of Aarhus, 8000 Aarhus C, Denmark. ${ }^{3}$ The Water and Salt Research Center, Institute of Anatomy, University of Aarhus Aarhus C, Denmark.

\section{Authors' contributions}

All authors have made substantial contribution in designing the study and collection of data. They have all contributed in writing the manuscript and have approved the final version.

\section{Competing interests}

The authors declare that they have no competing interests.

Received: 1 November 2009 Accepted: 28 October 2010 Published: 28 October 2010

\section{References}

1. Kwon TH, Nielsen J, Knepper MA, Frokiaer J, Nielsen S: Angiotensin II AT1 receptor blockade decreases vasopressin-induced water reabsorption and AQP2 levels in NaCl-restricted rats. Am J Physiol Renal Physiol 2005, 288:F673-F684

2. Amlal H, Chen Q, Habo K, Wang Z, Soleimani M: Fasting downregulates renal water channel AQP2 and causes polyuria. Am J Physiol Renal Physiol 2001, 280:F513-F523.

3. Funder JW: Mineralocorticoid receptors: distribution and activation. Heart Fail Rev 2005, 10:15-22.

4. Kim SW, Kim JW, Choi KC, Ma SK, Oh Y, Jung JY, Kim J, Lee J: Indomethacin enhances shuttling of aquaporin-2 despite decreased abundance in rat kidney. J Am Soc Nephrol 2004, 15:2998-3005.

5. Stokes JB, Kokko JP: Inhibition of sodium transport by prostaglandin E2 across the isolated, perfused rabbit collecting tubule. J Clin Invest 1977, 59:1099-1104

6. Wang W, Li C, Nejsum LN, Li H, Kim SW, Kwon TH, Jonassen TE, Knepper MA, Thomsen K, Frokiaer J, Nielsen S: Biphasic effects of ANP infusion in conscious, euvolumic rats: roles of $A Q P 2$ and $E N a C$ trafficking. Am J Physiol Renal Physiol 2006, 290:F530-F541.

7. Chen L, Reif MC, Schafer JA: Clonidine and PGE2 have different effects on $\mathrm{Na}+$ and water transport in rat and rabbit CCD. Am J Physiol 1991, 261: F126-F136.

8. Breyer MD, Breyer RM: Prostaglandin E receptors and the kidney. Am J Physiol Renal Physiol 2000, 279:F12-F23.

9. Hebert RL, Jacobson HR, Breyer MD: PGE2 inhibits AVP-induced water flow in cortical collecting ducts by protein kinase $C$ activation. Am J Physiol 1990, 259:F318-F325.

10. Pedersen RS, Bentzen $H$, Bech JN, Pedersen EB: Effect of water deprivation and hypertonic saline infusion on urinary AQP2 excretion in healthy humans. Am J Physiol Renal Physiol 2001, 280:F860-F867.

11. Jensen KT, Carstens J, Ivarsen P, Pedersen EB: A new, fast and reliable radioimmunoassay of brain natriuretic peptide in human plasma. Reference values in healthy subjects and in patients with different diseases. Scand J Clin Lab Invest 1997, 57:529-540.

12. Pedersen EB, Eiskjaer $H$, Madsen B, Danielsen $H$, Egeblad M, Nielsen CB: Effect of captopril on renal extraction of renin, angiotensin II, atrial natriuretic peptide and vasopressin, and renal vein renin ratio in patients with arterial hypertension and unilateral renal artery disease. Nephrol Dial Transplant 1993, 8:1064-1070.

13. Hebert RL, Jacobson HR, Breyer MD: Prostaglandin E2 inhibits sodium transport in rabbit cortical collecting duct by increasing intracellular calcium. J Clin Invest 1991, 87:1992-1998.

14. lino $\mathrm{Y}$, Imai M: Effects of prostaglandins on $\mathrm{Na}$ transport in isolated collecting tubules. Pflugers Arch 1978, 373:125-132.

15. Chen J, Zhao M, He W, Milne GL, Howard JR, Morrow J, Hebert RL, Breyer RM, Chen J, Hao CM: Increased dietary $\mathrm{NaCl}$ induces renal medullary PGE2 production and natriuresis via the EP2 receptor. Am J Physiol Renal Physiol 2008, 295:F818-F825.

16. Kim GH, Choi NW, Jung JY, Song JH, Lee CH, Kang CM, Knepper MA: Treating lithium-induced nephrogenic diabetes insipidus with a COX-2 inhibitor improves polyuria via upregulation of AQP2 and NKCC2. Am $J$ Physiol Renal Physiol 2008, 294:F702-F709.

17. Rouch AJ, Kudo LH: Role of PGE(2) in alpha(2)-induced inhibition of AVPand cAMP-stimulated $\mathrm{H}(2) \mathrm{O}, \mathrm{Na}(+)$, and urea transport in rat IMCD. Am J Physiol Renal Physiol 2000, 279:F294-F301.

18. Ando $Y$, Asano $Y$ : Luminal prostaglandin E2 modulates sodium and water transport in rabbit cortical collecting ducts. Am J Physiol 1995, 268 : F1093-F1101.

19. Canessa CM, Schafer JA: AVP stimulates $\mathrm{Na}+$ transport in primary cultures of rabbit cortical collecting duct cells. Am J Physiol 1992, 262:F454-F461.

20. Fuller PJ, Young MJ: Mechanisms of mineralocorticoid action. Hypertension 2005, 46:1227-1235.

21. Loffing J, Korbmacher C: Regulated sodium transport in the renal connecting tubule (CNT) via the epithelial sodium channel (ENaC). Pflugers Arch 2009, 458:111-135.

22. Kimura T, Abe K, Ota K, Omata K, Shoji M, Kudo K, Matsui K, Inoue M, Yasujima M, Yoshinaga K: Effects of acute water load, hypertonic saline infusion, and furosemide administration on atrial natriuretic peptide and vasopressin release in humans. J Clin Endocrinol Metab 1986, 62:1003-1010.

23. Abriel $H_{1}$ Horisberger JD: Feedback inhibition of rat amiloride-sensitive epithelial sodium channels expressed in Xenopus laevis oocytes. $J$ Physiol 1999, 516(Pt 1):31-43.

24. Starklint J, Bech JN, Pedersen EB: Down-regulation of urinary AQP2 and unaffected response to hypertonic saline after 24 hours of fasting in humans. Kidney Int 2005, 67:1010-1018.

25. Buemi M, Di PG, Ruello A, Floccari F, Aloisi C, Latassa G, Corsonello A, Sturiale A, Corica F, Frisina N: Effect of a prostacyclin analogue, iloprost, on urinary aquaporin-2 excretion in humans. Nephron 2002, 91:197-202.

26. Fejes-Toth G, Magyar A, Walter J: Renal response to vasopressin after inhibition of prostaglandin synthesis. Am J Physiol 1977, 232:F416-F423.

27. Ciabattoni G, Cinotti GA, Pierucci A, Simonetti BM, Manzi M, Pugliese F, Barsotti P, Pecci G, Taggi F, Patrono C: Effects of sulindac and ibuprofen in patients with chronic glomerular disease. Evidence for the dependence of renal function on prostacyclin. N Engl J Med 1984, 310:279-283.

28. Roberts DG, Gerber JG, Barnes JS, Zerbe GO, Nies AS: Sulindac is not renal sparing in man. Clin Pharmacol Ther 1985, 38:258-265. 
29. Coleman RA, Smith WL, Narumiya S: International Union of Pharmacology classification of prostanoid receptors: properties, distribution, and structure of the receptors and their subtypes. Pharmacol Rev 1994, 46:205-229.

30. Hebert RL, Jacobson HR, Fredin D, Breyer MD: Evidence that separate PGE2 receptors modulate water and sodium transport in rabbit cortical collecting duct. Am J Physiol 1993, 265:F643-F650.

31. Stokes JB: Effect of prostaglandin E2 on chloride transport across the rabbit thick ascending limb of Henle. Selective inhibitions of the medullary portion. J Clin Invest 1979, 64:495-502.

32. Tamma G, Wiesner B, Furkert J, Hahm D, Oksche A, Schaefer M, Valenti G, Rosenthal W, Klussmann E: The prostaglandin E2 analogue sulprostone antagonizes vasopressin-induced antidiuresis through activation of Rho. J Cell Sci 2003, 116:3285-3294.

33. Buemi M, Corica F, Di PG, Aloisi C, Sofi M, Casuscelli T, Floccari F, Senatore $M$, Corsonello A, Frisina N: Water immersion increases urinary excretion of aquaporin-2 in healthy humans. Nephron 2000, 85:20-26.

34. de SS, Nielsen J, Olesen ET, Dimke H, Kwon TH, Frokiaer J, Nielsen S: Longterm aldosterone treatment induces decreased apical but increased basolateral expression of AQP2 in CCD of rat kidney. Am J Physiol Renal Physiol 2007, 293:F87-F99.

35. Lee J, Yoo K, Kim SW, Jung KH, Ma SK, Lee YK, Kim WY, Kim J, Choi KC: Decreased expression of aquaporin water channels in denervated rat kidney. Nephron Physiol 2006, 103:170-178.

36. Lee YJ, Song IK, Jang KJ, Nielsen J, Frokiaer J, Nielsen S, Kwon TH: Increased AQP2 targeting in primary cultured IMCD cells in response to angiotensin II through AT1 receptor. Am J Physiol Renal Physiol 2007, 292: F340-F350.

37. Marples D, Frokiaer J, Knepper MA, Nielsen S: Disordered water channel expression and distribution in acquired nephrogenic diabetes insipidus. Proc Assoc Am Physicians 1998, 110:401-406.

38. Wong NL, Tsui JK: Angiotensin II upregulates the expression of vasopressin V2 mRNA in the inner medullary collecting duct of the rat. Metabolism 2003, 52:290-295.

39. Hager H, Kwon TH, Vinnikova AK, Masilamani S, Brooks HL, Frokiaer J, Knepper MA, Nielsen S: Immunocytochemical and immunoelectron microscopic localization of alpha-, beta-, and gamma-ENaC in rat kidney. Am J Physiol Renal Physiol 2001, 280:F1093-F1106.

\section{Pre-publication history}

The pre-publication history for this paper can be accessed here: http://www.biomedcentral.com/1471-2369/11/28/prepub

\section{doi:10.1186/1471-2369-11-28}

Cite this article as: Lauridsen et al:: Increased renal sodium absorption by inhibition of prostaglandin synthesis during fasting in healthy man. A possible role of the epithelial sodium channels. BMC Nephrology 2010 $11: 28$.

\section{Submit your next manuscript to BioMed Central and take full advantage of:}

- Convenient online submission

- Thorough peer review

- No space constraints or color figure charges

- Immediate publication on acceptance

- Inclusion in PubMed, CAS, Scopus and Google Scholar

- Research which is freely available for redistribution

Submit your manuscript at www.biomedcentral.com/submit
Biomed Central 